\title{
Influence of the salt bath agitation and austempering temperature on the microstructure of austempered ductile iron
}

\author{
Nikša Čatipović ${ }^{1, *}$, Dražen Živković ${ }^{1}, Z^{2}$ vonimir Dadić ${ }^{1}$, Marin Viceić ${ }^{1}$ \\ ${ }^{1}$ Faculty of Electrical Engineering, Mechanical Engineering and Naval Architecture, University of \\ Split, Ruđera Boškovića 32, 21000 Split, Republic of Croatia; Drazen.Zivkovic@fesb.hr, \\ Zvonimir.Dadic@fesb.hr, Marin.Viceic@fesb.hr \\ * Correspondence: Niksa.Catipovic@fesb.hr; Tel.: +385914305926
}

\begin{abstract}
In this paper the influence of austempering temperature and salt bath agitation on the final microstructure and mechanical properties of the ferritic ductile iron were studied. 17 samples had been subjected to different heat treatment parameters. Different microstructures were recorded upon the completion of the tests. From the obtained micro images, it is obvious that both the austempering temperature and salt bath agitation affect the final microstructure of the austempered ductile iron. Lower austempering temperatures and salt bath agitation produce more ausferrite in the microstructure, hence the harder and tougher phases are present. This was confirmed with hardness and toughness test of the 17 heat-treated samples. Lower austempering temperatures give more ausferrite phase and therefore higher hardness, but hardness decreases with increasing austempering temperatures. Toughness rises with rising austempering temperatures, but drops significantly with temperatures above $395^{\circ} \mathrm{C}$ because of the final microstructure.
\end{abstract}

Keywords: austempered ductile iron; austempering parameters; microstructure; mechanical properties; salt bath agitation.

\section{Introduction}

Over the last years, the market has been facing huge demand for tough, durable and economically viable materials. Ductile cast iron is one such material. When ductile iron is subjected to the isothermal heat treatment, a completely new material is produced, known as austempered ductile iron - ADI. ADI has significantly better mechanical properties than plain ductile iron, [1]. Austempered ductile iron possesses a unique microstructure called ausferrite which is a mixture of fine acicular ferrite and stable, high carbon enriched retained austenite, [2,3]. That new microstructure results with properties superior to many iron and aluminium alloys. Compared with perlitic, ferritic or martensitic microstructures, ausferrite exhibits twice the strength for the given ductility level obtained by the conventional heat treatment, [3]. The mechanical properties of the austempered ductile iron depend on its ausferritic microstructure. Austempered matrix provides better tensile strength and ductility ration than any other type of ductile cast iron. Different combinations of mechanical properties, as a result of ausferritic microstructure of the austempered ductile iron, can be obtained by combination of heat treatment parameters and alloying elements, [4].

Heat treatment of the austempered ductile iron consists of austenitization of the ductile iron, quenching in the austempering medium and holding on the austempering temperature and then cooling to the room temperature, [5], Fig. 1. 


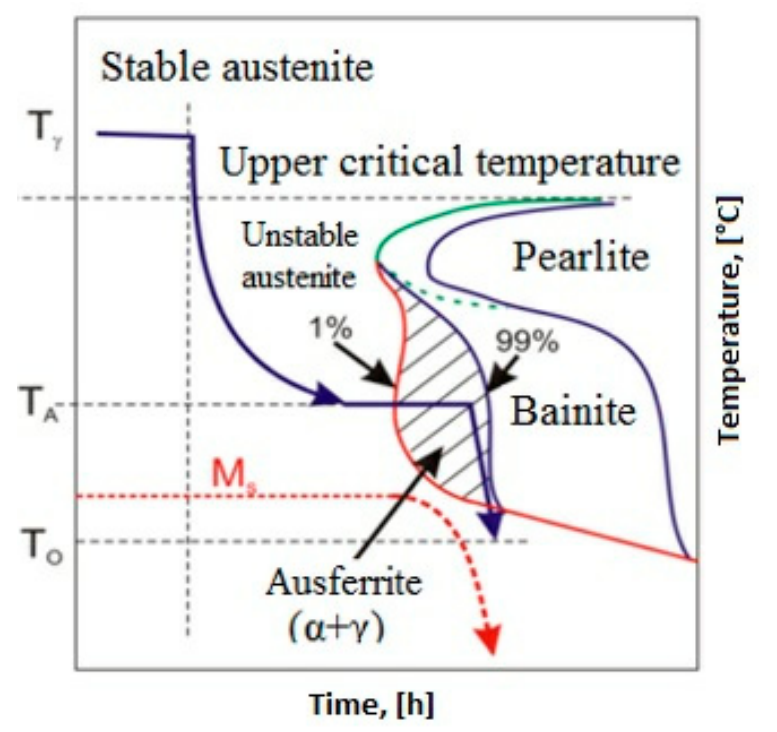

Figure 1. Austempering heat treatment of the ductile iron, [5]

Several authors, $[2,3,6]$, have correctly stated that during the austempering process, ADI undergoes the two stage transformation process. In the first stage of the transformation, the austenite $(\gamma)$ decomposes into bainitic ferrite $(\alpha)$ and carbon enriched retained austenite $\left(\gamma_{h c}\right)$, so-called ausferrite. In the second stage of the transformation, the carbon enriched retained austenite $\left(\gamma_{h c}\right)$ further decomposes on ferrite $(\alpha)$ and carbides. This decomposition will occur if the ductile iron is held for too long at the austempering temperature, [2]. The occurrence of carbides in the microstructure makes the material brittle, hence such reaction should be avoided. Therefore, the optimal mechanical properties of ADI are achieved upon the completion of the first stage of the transformation but before the beginning of the second stage of the transformation, i.e. within the so-called "time window", [7, 8].

\section{Salt bath}

The most commonly used austempering medium is the salt bath composed of sodium and potassium nitrate $\left(\mathrm{NaNO}_{3}+\mathrm{KNO}_{3}\right)$ in the $50 \%: 50 \%$ ratio. The operating temperature range of this salt composition is between $160^{\circ} \mathrm{C}$ and $550^{\circ} \mathrm{C}$, depending on the chemical composition of the salt. The austempering conversion can be done in lead bath, but since lead has melting point at $327^{\circ} \mathrm{C}$, that narrows the temperature range of the heat treatment process. Oil bath can be exceptionally used, but with high dose of caution, $[9,10]$.

Salt baths are most often used for austempering heat treatment. They are also used for tempering, annealing, austenitization, quenching, etc. Chemical composition of salt baths plays a key role during the heat treatment. Molten salts are completely dissolved on cations and anions, which are thermally very stable. They have low vapour pressure and excellent thermal and electrical conductivity. Workpieces deformations are very small, if they occur at all, because the heat dissipation is very fast and uniform. These salts have low viscosity but high solubility. The ability to dissolve the gases is good and increases with rising temperatures. Some molten salts can even dissolve metals, [11].

The salt bath is most commonly used medium for austempering of ductile iron because, [10, 11]:

- the bath working temperature ranges are from $160^{\circ} \mathrm{C}$ to $550^{\circ} \mathrm{C}$,

- it can be used for quenching processes with discontinuous change in cooling rate,

- it conducts heat very fast and it is not flammable, 
- it eliminates the problem of the vapour bubble at the initial cooling stage,

- its viscosity is uniform through a wide range of temperatures,

- its viscosity is low at austempering temperatures (almost as the viscosity of water at room temperature), which reduces losses during the removal of the workpiece,

- it remains stable at working temperatures and is completely water-soluble, which eases subsequent cleaning,

- the salt can easily be extracted from the water used for cleaning using evaporation methods,

- by changing the working temperature, agitating and adding water cooling intensity can be significantly affected. It is common that at working temperatures from $160^{\circ} \mathrm{C}$ to $290^{\circ} \mathrm{C}$ the water content is from $0,5 \%$ to $2 \%$.

Table 1. shows the compositions and characteristics of the two variations of the most commonly used salt baths. Narrow range salt is only used for austempering heat treatment, while wide range salt is used for tempering, martempering and other tempering processes.

Table 1. Compositions and characteristics of austempering salt baths, [10]

\begin{tabular}{|c|c|c|}
\hline & Narrow range & Wide range \\
\hline Sodium nitrate, $\%$ & $45-55$ & $0-25$ \\
\hline Calcium nitrate, $\%$ & $45-55$ & $45-55$ \\
\hline Sodium nitrite, $\%$ & $\ldots$ & $25-55$ \\
\hline Melting point, $\mathrm{T}\left[{ }^{\circ} \mathrm{C}\right]$ & 220 & $150-165$ \\
\hline $\begin{array}{c}\text { Working temperature, } \mathrm{T} \\
{\left[{ }^{\circ} \mathrm{C}\right]}\end{array}$ & $260-595$ & $175-540$ \\
\hline
\end{tabular}

Salts for salt baths are easily available from specialized manufacturers who specialize in heat treatment of metals. One of these manufacturers is "Hef Durferrit" [12], which offers a variety of salts, depending on their specific application.

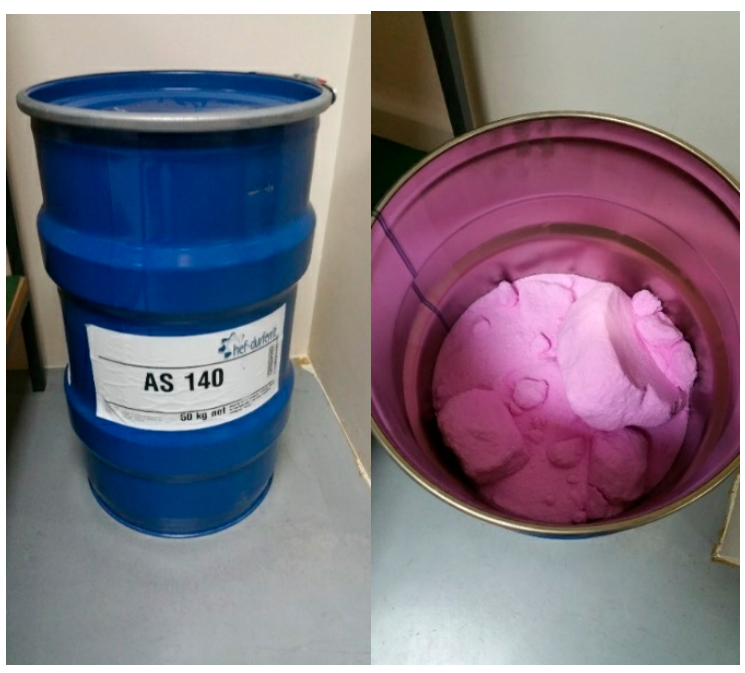




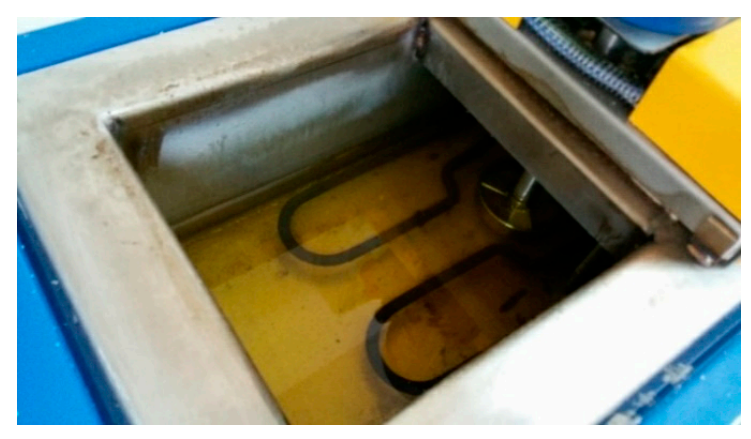

Figure 2.1. Salt AS 140 and salt bath ready for experiments

\section{Experimental work}

The task of this paper was to investigate the effect of salt bath agitation and austempering temperature on the final microstructure of the ADI. The characteristic microstructure of ADI is called ausferrite, obtaining of which was explained in the previous chapter.

Based on previous studies, [13, 14], and available literature, [15, 16, 17, 18], these heat treatment parameters were chosen: austenitization temperature of $900^{\circ} \mathrm{C}$, holding time at austenitization temperature of $1 \mathrm{~h}$, holding time at the austempering temperature of $1 \mathrm{~h}$ while the austempering temperature ranged from $230^{\circ} \mathrm{C}$ to $450^{\circ} \mathrm{C}$. An experiment plan was developed using "Design Expert" software. The best model for planning the experiment plan in respect to input parameters was Response Surface study type with D-optimal initial design and Cubic model design. That model resulted in 17 experiments required to obtain mathematical model which would be able to describe and predict mechanical properties in relation to input parameters, Table 2.

Table 2. Experiment plan

\begin{tabular}{|c|c|c|c|}
\hline Sample label & $\begin{array}{c}\text { Experiment } \\
\text { number }\end{array}$ & $\begin{array}{c}\text { Austempering } \\
\text { temperature, }\left[{ }^{\circ} \mathrm{C}\right]\end{array}$ & $\begin{array}{c}\text { Salt bath } \\
\text { agitation }\end{array}$ \\
\hline 13 & 1 & 230 & With \\
\hline 3 & 2 & 230 & With \\
\hline 11 & 3 & 395 & Without \\
\hline 17 & 4 & 307 & With \\
\hline 12 & 5 & 258 & Without \\
\hline 1 & 6 & 394 & With \\
\hline 15 & 7 & 230 & Without \\
\hline 14 & 8 & 450 & Without \\
\hline 16 & 9 & 450 & With \\
\hline 4 & 10 & 230 & Without \\
\hline 5 & 11 & 450 & With \\
\hline 6 & 12 & 307 & Without \\
\hline 8 & 13 & 352 & With \\
\hline 7 & 14 & 307 & With \\
\hline 2 & 15 & 450 & Without \\
\hline 10 & 16 & 423 & With \\
\hline 9 & 17 & 368 & Without \\
\hline
\end{tabular}

As a starting material, ductile cast iron was obtained from Split Shipyard. The chemical composition of samples is given in Table 3. 
Table 3. Chemical composition of the ductile iron

\begin{tabular}{|l|l|l|l|l|l|l|l|}
\hline Label & $\begin{array}{l}\text { C } \\
(\%)\end{array}$ & $\begin{array}{l}\text { Si } \\
(\%)\end{array}$ & $\begin{array}{l}\text { Mn } \\
(\%)\end{array}$ & $\begin{array}{l}\mathbf{P} \\
(\%)\end{array}$ & $\begin{array}{l}\text { S } \\
(\%)\end{array}$ & $\begin{array}{l}\mathbf{C u} \\
(\%)\end{array}$ & $\begin{array}{l}\mathbf{M g} \\
(\%)\end{array}$ \\
\hline $\begin{array}{l}\text { NL40- } \\
\text { KF }\end{array}$ & 3,63 & 2,52 & 0,20 & 0,04 & 0,008 & 0,04 & 0,047 \\
\hline
\end{tabular}

From the starting Y-blocks, Charpy test samples were cut out, Fig. 3.1. After microstructural analysis the hardness and toughness measurement tests were performed. Samples were made in accordance with ISO 148-1 norm.

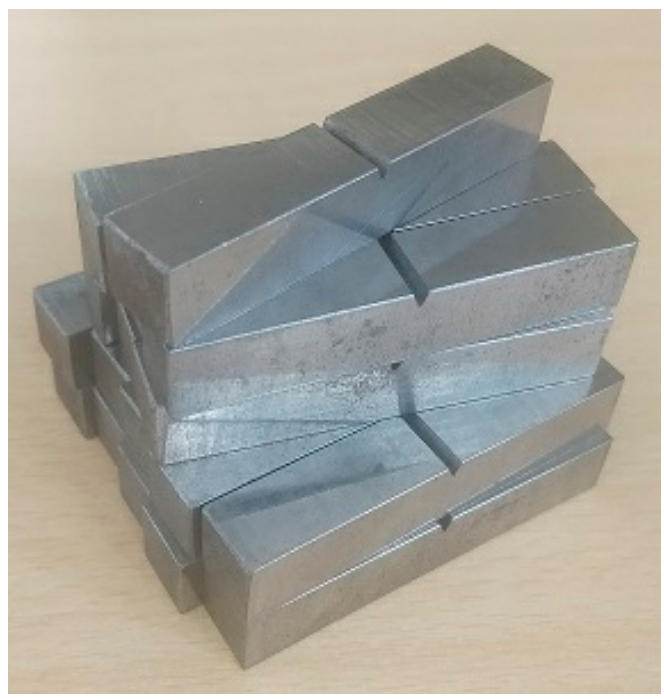

Figure 3.1. Standardized Charpy samples ready for experiments

Prior to the start of the experimentation, the initial microstructure of the ductile iron had been taken Fig. 3.2. The figure shows ferrite ductile iron with very small amount of perlite in the microstructure.

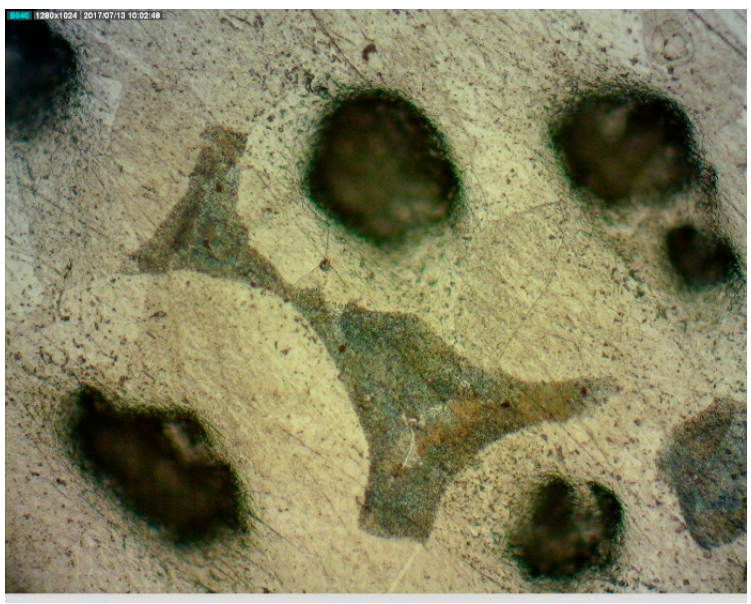

Figure 3.2. As cast microstructure, magnification $200 x$ 


\section{Results}

After the heat treatment was conducted, all of the samples were prepared for the microstructural analysis. The preparation related to the sample surfaces adaptation for microstructural analysis after the austempering. Samples were ground on the abrasive stripes of different grain sizes. The roughness of thus prepared surfaces was further reduced on the mechanical polishing wheel, Figure 4.1.

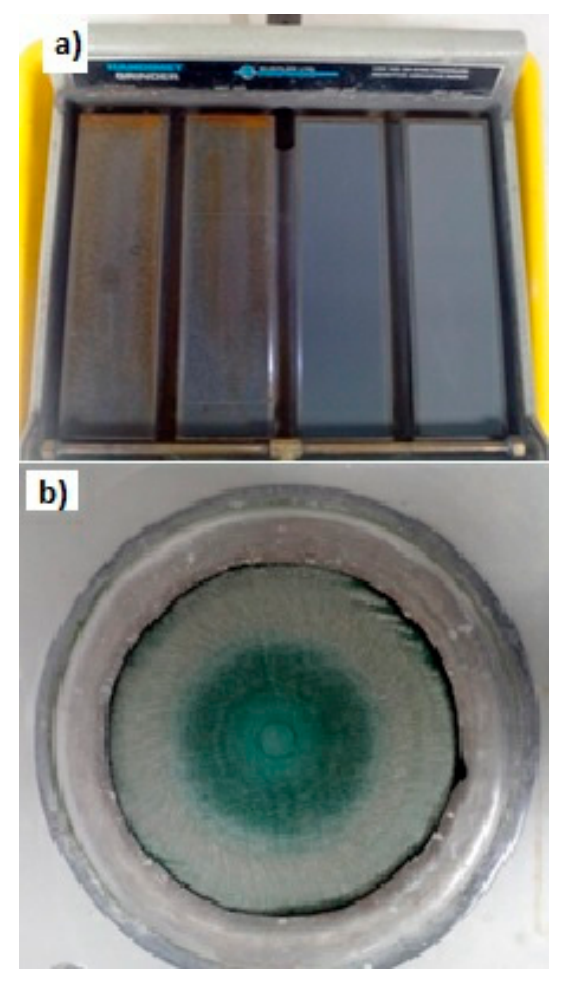

Figure 4.1. a) Abrasive stripe, b) mechanical polishing wheel.

As an abrasive agent on the wheel, emulsion with clay as a polishing medium was applied (aluminium oxide + water). Final step of the surface preparation consisted of etching it with nital (mixture of alcohol and 3\% nitric acid). A light microscope was connected to a computer that projected microstructure on the computer screen via the "DinoCapture" program package.

The following figures show different microstructures obtained with respect to the austempering temperature and salt bath agitation. Figures 4.2. - 4.5. show microstructures after austempering at different temperatures with salt bath mixing. 


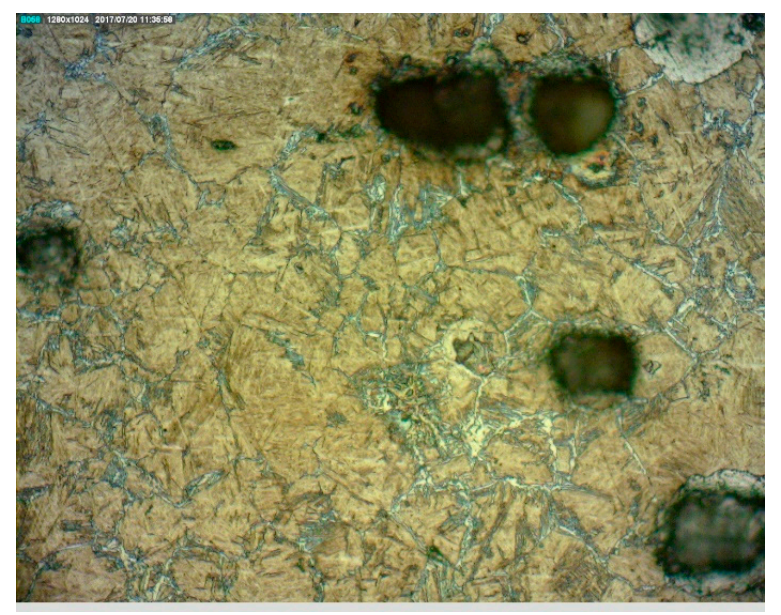

Figure 4.2. Austempered at $230^{\circ} \mathrm{C}$ with salt bath agitation, magnification $200 \mathrm{x}$

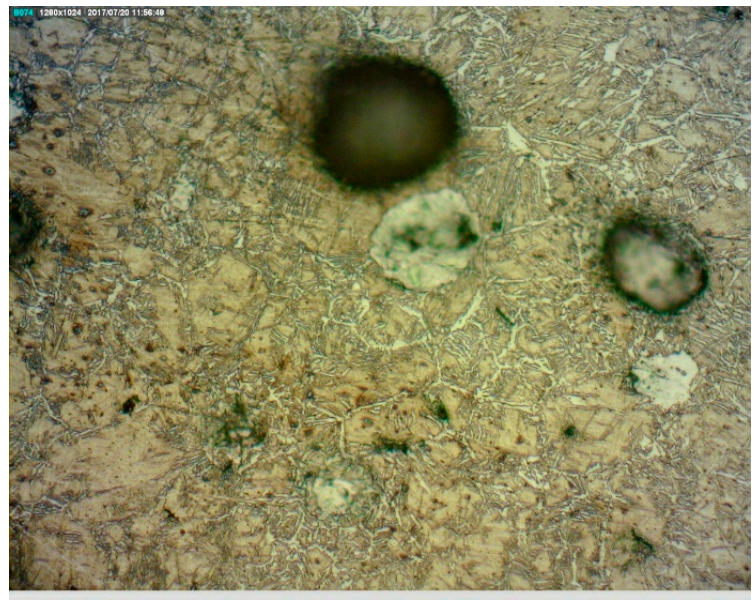

Figure 4.3. Austempered at $307^{\circ} \mathrm{C}$ with salt bath agitation, magnification $200 \mathrm{x}$

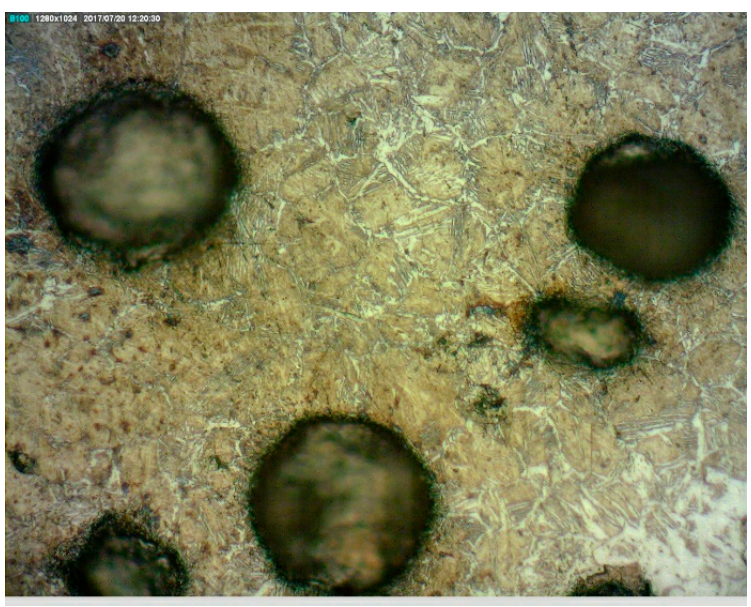

Figure 4.4. Austempered at $352^{\circ} \mathrm{C}$ with salt bath agitation, magnification 200x 


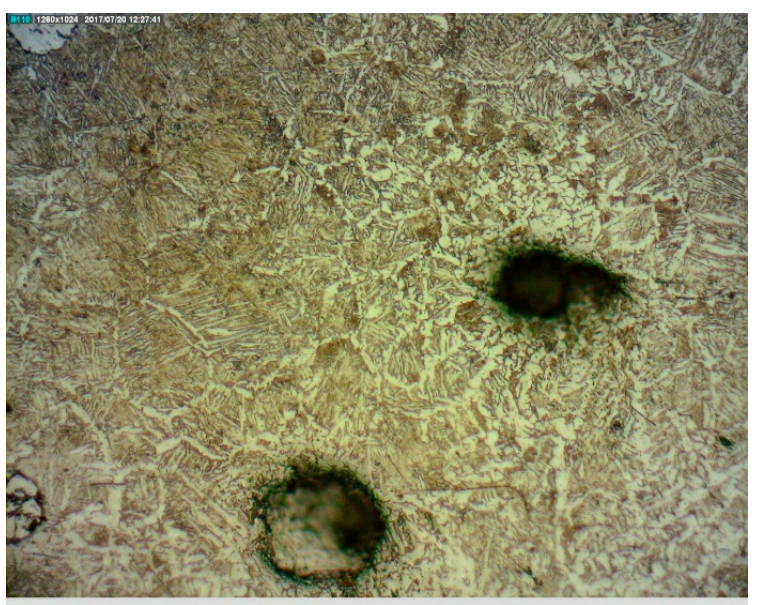

Figure 4.5. Austempered at $423^{\circ} \mathrm{C}$ with salt bath agitation, magnification $200 \mathrm{x}$

Figures 4.6. - 4.9. show microstructures after austempering at different temperatures without salt bath agitation.

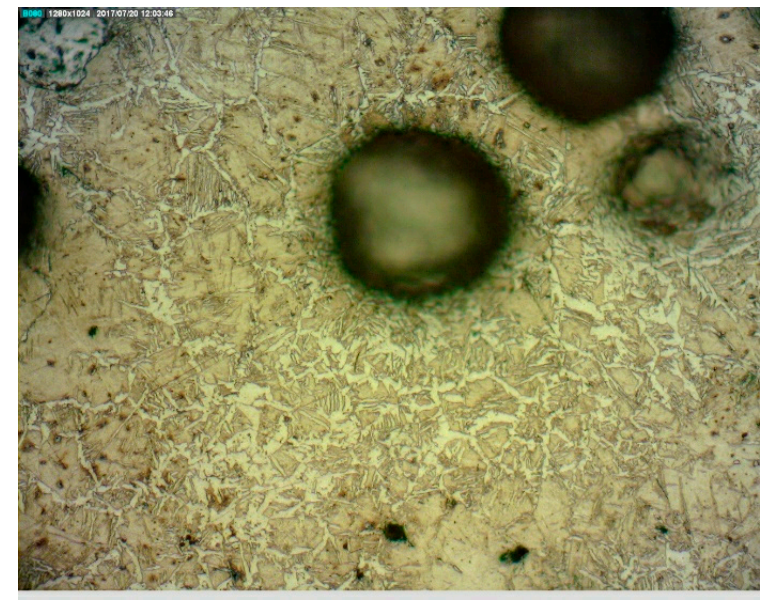

Figure 4.6. Austempered at $258^{\circ} \mathrm{C}$ without salt bath agitation, magnification $200 \mathrm{x}$

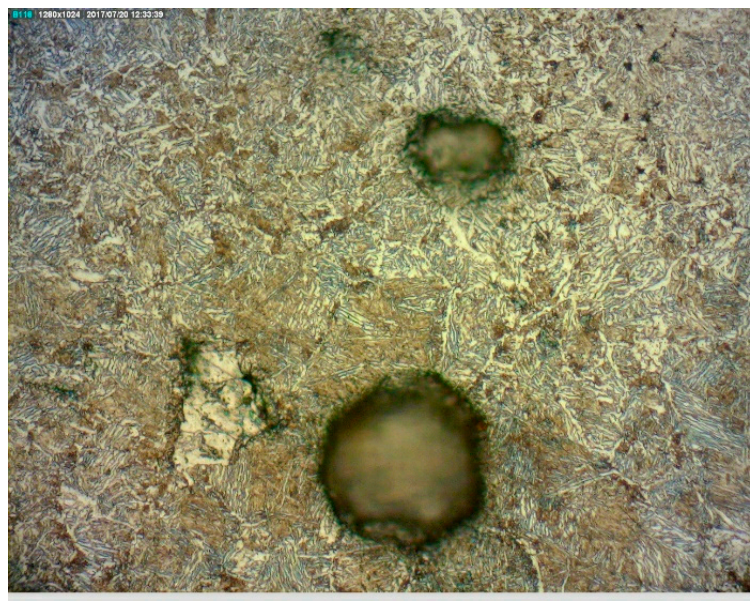

Figure 4.7. Austempered at $368^{\circ} \mathrm{C}$ without salt bath agitation, magnification 200x 


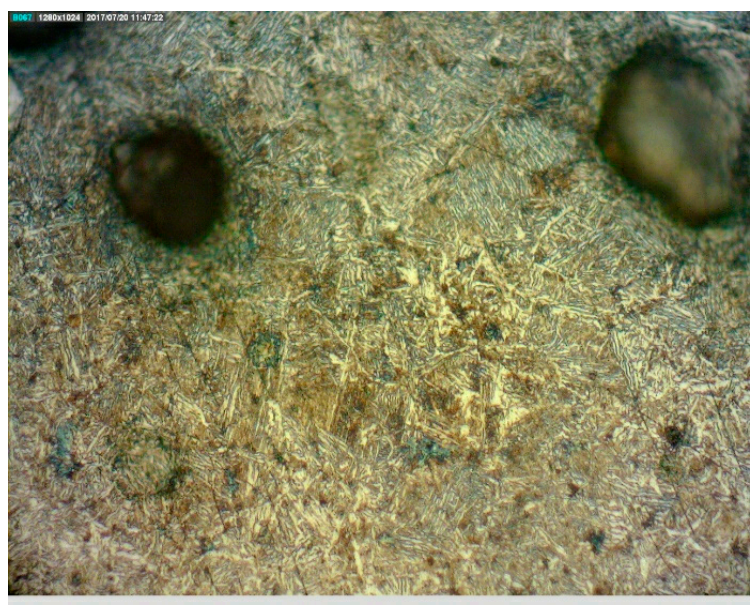

Figure 4.8. Austempered at $395^{\circ} \mathrm{C}$ without salt bath agitation, magnification $200 \mathrm{x}$

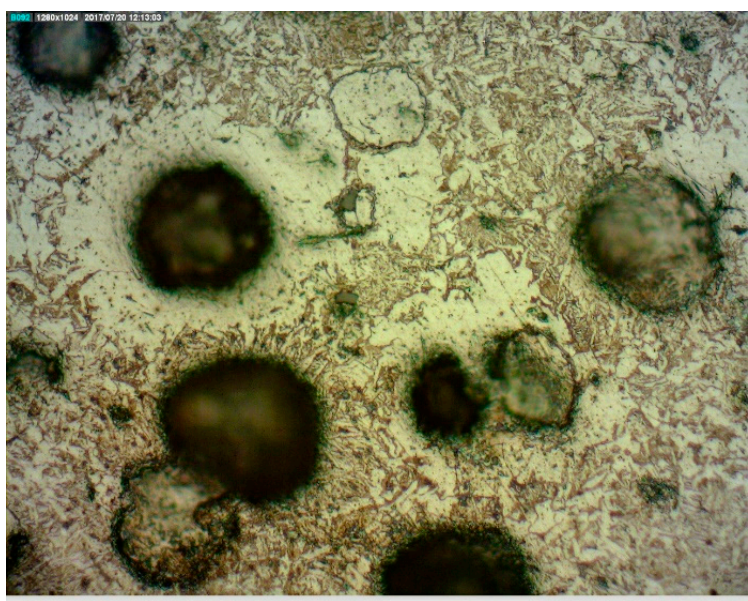

Figure 4.9. Austempered at $450^{\circ} \mathrm{C}$ without salt bath agitation, magnification $200 \mathrm{x}$

After the microstructure of the heat treated samples had been analyzed, mechanical properties were tested. Firstly, the hardness was measured using the universal hardness measuring machine "Amsler OTTO Wolpert-Werke GMBA", model "Dia Testor 2 Rc-S", Figure 4.10. Five measurements using method Vickers HV10 were made on each sample and the average value was calculated from those five measurements. 


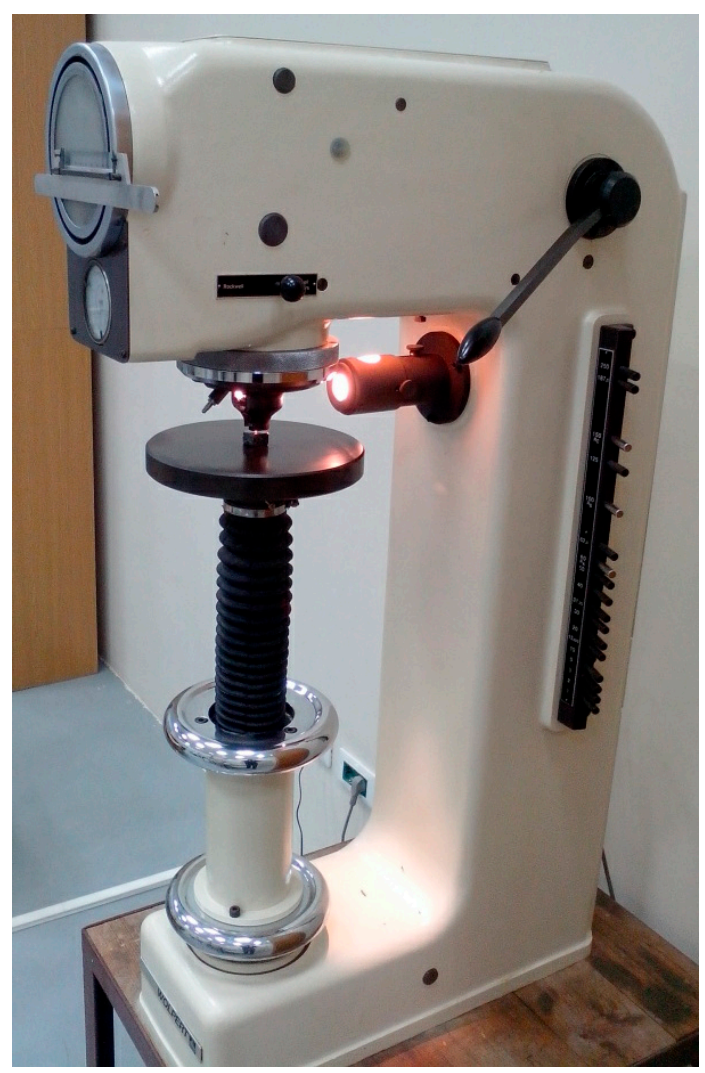

Figure 4.10. Wolpert hardness measuring machine

The next step was to measure toughness on the Charpy pendulum "Amsler OTTO Wolpert-Werke GMBA", model "PW 30/15 K", Figure 4.11.

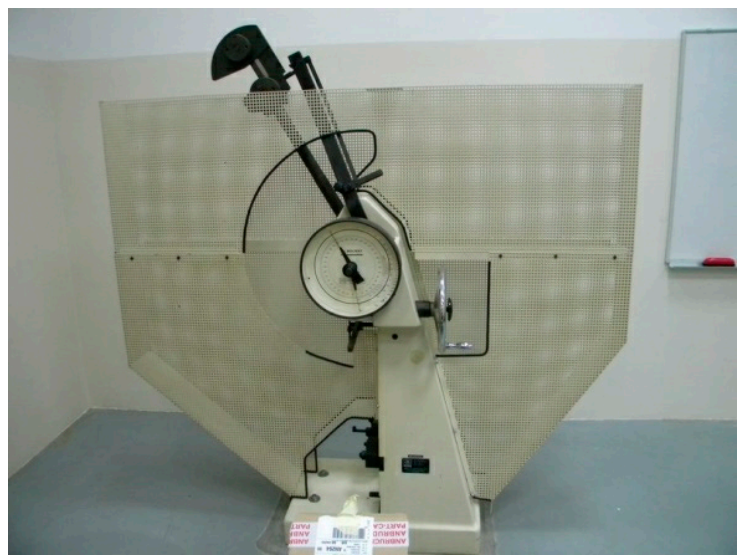

Figure 4.11. Wolpert Charpy pendulum

The results obtained from hardness and toughness tests are shown in Table 4.

Table 4. Obtained results of mechanical tests

\begin{tabular}{|c|c|c|}
\hline Sample label & $\begin{array}{c}\text { Hardness, } \\
\text { [HV10] }\end{array}$ & $\begin{array}{c}\text { Toughness, } \\
\text { [J] }\end{array}$ \\
\hline 1 & 246 & 45 \\
\hline 2 & 214 & 36 \\
\hline
\end{tabular}




\begin{tabular}{|c|c|c|}
\hline 3 & 431 & 36 \\
\hline 4 & 315 & 36 \\
\hline 5 & 219 & 36 \\
\hline 6 & 256 & 40 \\
\hline 7 & 283 & 39 \\
\hline 8 & 251 & 42 \\
\hline 9 & 231 & 45 \\
\hline 10 & 276 & 38 \\
\hline 11 & 251 & 44 \\
\hline 12 & 318 & 37 \\
\hline 13 & 393 & 35 \\
\hline 14 & 212 & 36 \\
\hline 15 & 355 & 36 \\
\hline 16 & 226 & 36 \\
\hline 17 & 326 & 40 \\
\hline
\end{tabular}

The final step was to input all of the obtained results into Design Expert software, conduct statistical analysis and check if the chosen model was significant. Using ANOVA statistical analysis as a part of Design Expert software gives great insight into behavior of each tested mechanical property in relation to heat treatment parameters. Figure 4.12. shows hardness variance analysis using ANOVA whereas Figure 4.13. shows change in hardness in respect to bath agitation and austempering temperature.

\begin{tabular}{|c|c|c|c|c|c|c|}
\hline \multirow{2}{*}{\multicolumn{7}{|c|}{$\begin{array}{l}\text { Response } 1 \text { Hardness } \\
\text { ANOVA for Response Surface Quadratic Model }\end{array}$}} \\
\hline & & & & & & \\
\hline \multicolumn{7}{|c|}{ Analysis of variance table [Partial sum of squares - Type III] } \\
\hline & Sum of & & Mean & $\mathbf{F}$ & p-value & \\
\hline Source & Squares & df & Square & Value & Prob $>\mathrm{F}$ & \\
\hline Model & 61410.98 & 4 & 15352.75 & 31.13 & $<0.0001$ & significant \\
\hline A-Austempering & 52622.47 & 1 & 52622.47 & 106.72 & $<0.0001$ & \\
\hline B-Bath agitation & 5840.59 & 1 & 5840.59 & 11.84 & 0.0049 & \\
\hline$A B$ & 1987.62 & 1 & 1987.62 & 4.03 & 0.0677 & \\
\hline$A^{2}$ & 4015.58 & 1 & 4015.58 & 8.14 & 0.0145 & \\
\hline Residual & 5917.25 & 12 & 493.10 & & & \\
\hline Lack of Fit & 3444.25 & 7 & 492.04 & 0.99 & 0.5211 & not significant \\
\hline Pure Error & 2473.00 & 5 & 494.60 & & & \\
\hline Cor Total & 67328.24 & 16 & & & & \\
\hline
\end{tabular}

Figure 4.12. Hardness variance analysis

As seen from Figure 4.12., quadratic model is the best suitable to define hardness changes of the tested samples. Used model is significant and that there is only $0.01 \%$ probability that "Model F-Value" this large could occur due to noise. The "Lack of Fit F-value" of 0.99 implies the Lack of Fit is not significant relative to the pure error. There is a $52.11 \%$ probability that a "Lack of Fit F-value" this large could occur due to noise. Non-significant lack of fit is good. 
Design-Expert@ Software

Hardness

- Design Points

- B1 With

$\Delta$ B2 Without

$\mathrm{X} 1=\mathrm{A}:$ : Austempering temperature $\mathrm{X} 2$ = B: Bath agitation

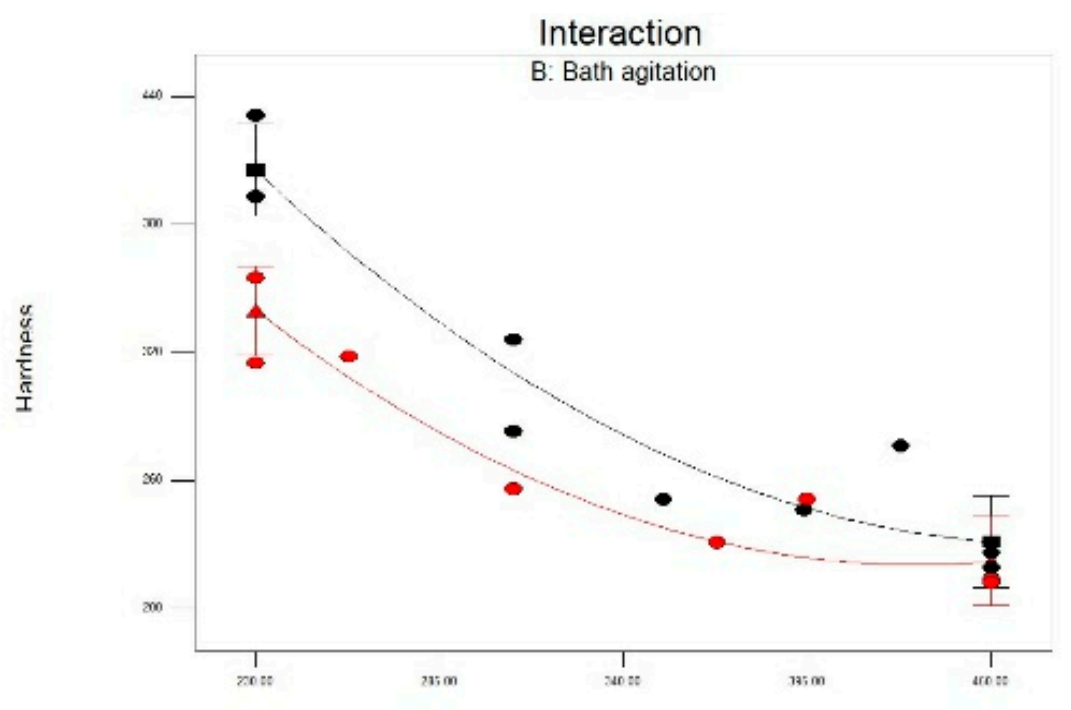

A: Austempering temperature

Figure 4.13. Hardness changes in respect to bath agitation and austempering temperatures

Figure 4.13. shows that there is a significant change in hardness due to bath agitation and different austempering temperature. Higher austempering temperatures provide lower hardness values, which is expected, because at lower temperatures harder phases occur and more harder phases are present in microstructure. From the figure can be seen that bath agitation increases final hardness of samples which can be explained with better heat dissipation when the salt bath is agitated and so the cooling rate is higher.

Figure 4.14. shows toughness variance analysis using ANOVA and Figure 4.15. shows change in toughness in respect to bath agitation and austempering temperature.

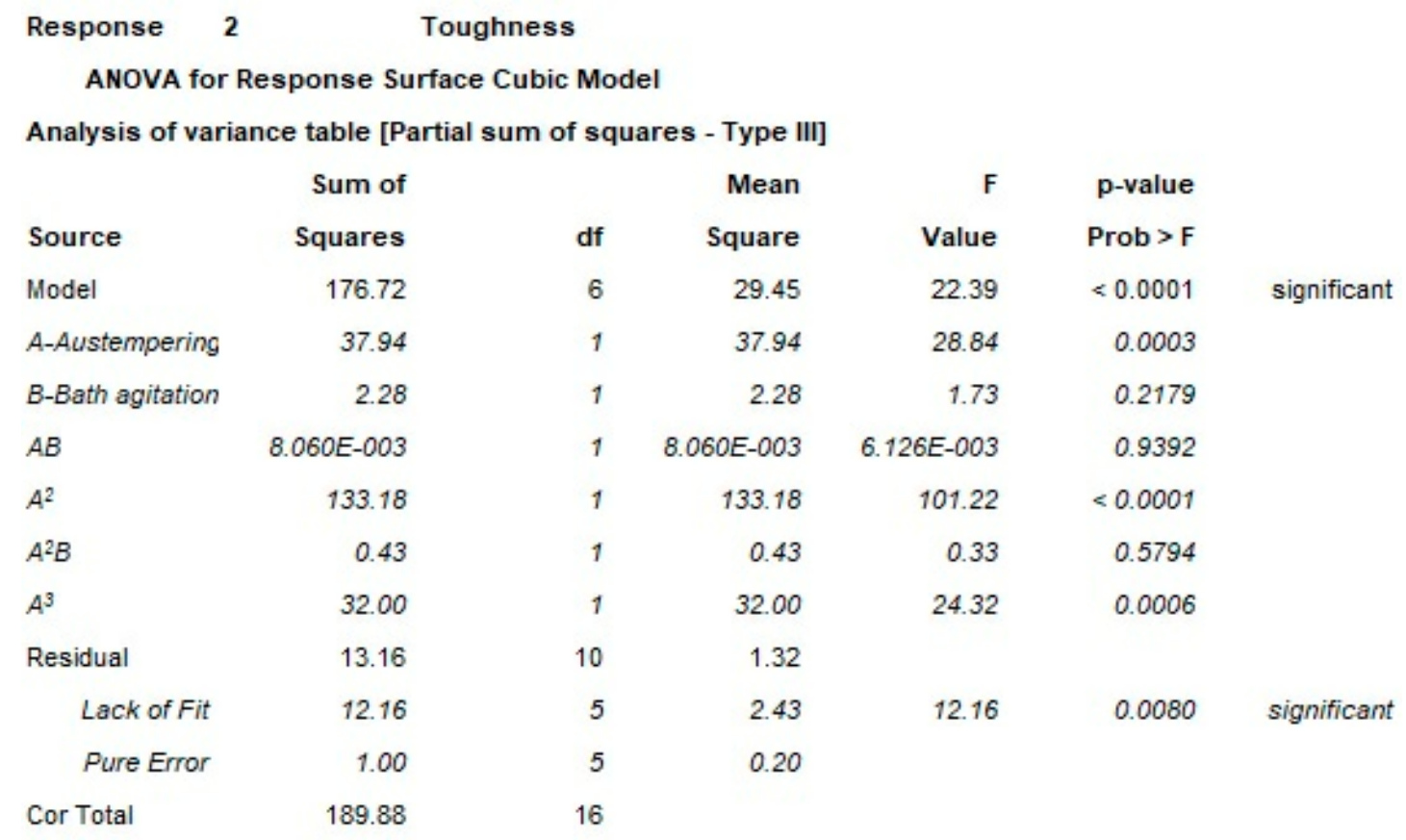

Figure 4.14. Toughness variance analysis 
As seen from Figure 4.14., the cubic model is best suitable to define toughness changes of the tested samples. Used model is significant and that there is only $0.01 \%$ probability that "Model F-Value" this large could occur due to noise. The "Lack of Fit F-value" of 12.16 implies the "Lack of Fit"? is significant. There is only a $0.80 \%$ probability that a "Lack of Fit F-value" this large could occur due to noise. Significant lack of fit is bad.

Design-Expertes Software

Toughness

- Design Points

- B1 With

- B2 Without

$\mathrm{X} 1=\mathrm{A}:$ Austempering temperature $\mathrm{X} 2=\mathrm{B}:$ Bath agitation

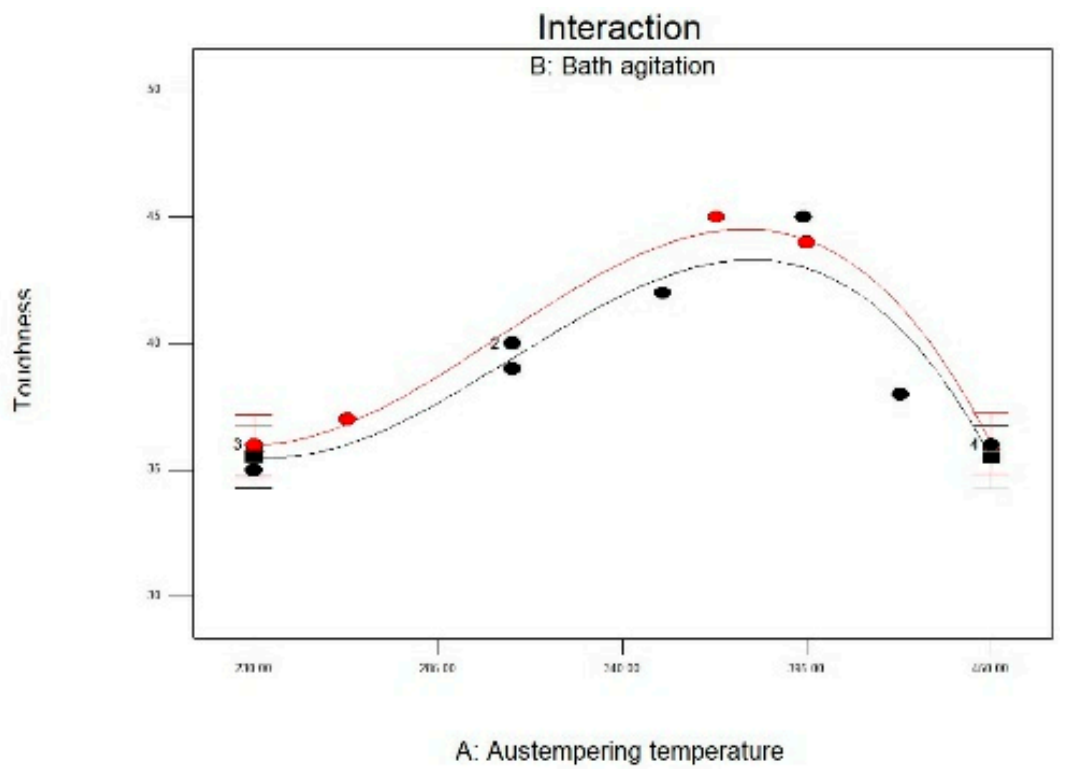

Figure 4.15. Toughness changes in respect to bath agitation and austempering temperatures

As seen from Figure 4.15. toughness significantly changes in respect to austempering temperature and bath agitation. However, the occurrence of lower toughness at temperatures above $395^{\circ} \mathrm{C}$ was completely unexpected. This can be explained by different amount of phases than on lower temperatures. At elevated temperatures there are smaller amounts of ausferrite phase than on lower temperatures so the mechanical properties, both hardness and toughness, are lower than expected. This can be explained with two facts, firstly austempering times should be longer than 1 hour which was used in this paper and secondly chemical composition of base ductile iron is obviously poorer in carbon than stated, since carbon diffusion enriches retained austenite to produce ausferrite. This is easily seen on microstructural images shown in this paper. Similar conclusions were given by other authors, [18].

Last step of the analysis was to obtain mathematical model from ANOVA which describes hardness and toughness changes in respect to bath agitation and austempering temperature. Two mathematical models are shown here, one for hardness, Figure 4.16. and the other for toughness, Figure 4.17 . 


\title{
Final Equation in Terms of Actual Factors:
}

\author{
Bath agitation With \\ Hardness $=$ \\ $+904.75125$ \\ -2.87546 * Austempering temperature \\ $+3.06369 \mathrm{E}-003$ *Austempering temperature ${ }^{2}$ \\ Bath agitation Without \\ Hardness $=$ \\ $+779.67218$ \\ -2.61752 *Austempering temperature \\ $+3.06369 \mathrm{E}-003{ }^{*}$ Austempering temperature ${ }^{2}$
}

Figure 4.16. Mathematical model for hardness prediction

Final Equation in Terms of Actual Factors:

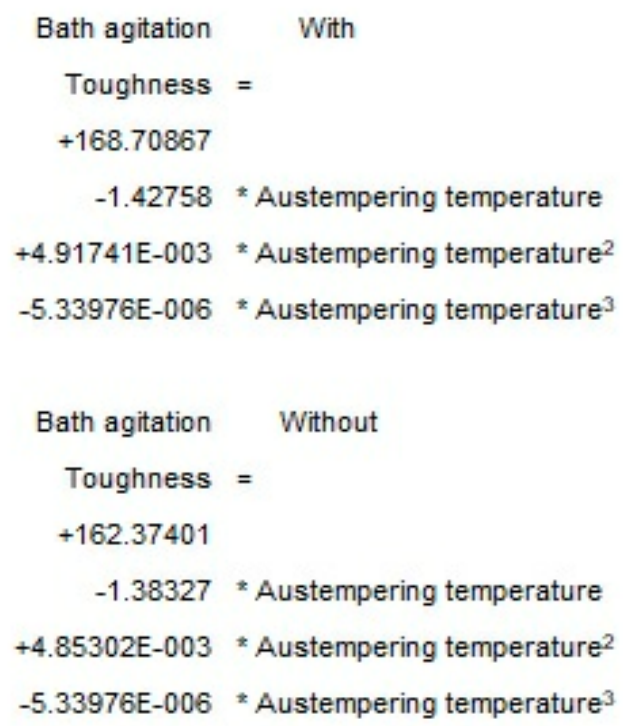

Figure 4.17. Mathematical model for toughness prediction

\section{Conclusion}

From the obtained microstructure images, it is clear that there has been a significant change in relation to the initial microstructure before the heat treatment. It is noticed that at lower austempering temperatures the microstructure is finer than at the higher austempering temperatures, regardless of whether the salt bath was agitating or not. 
It is also apparent that there is more ausferrite phase in the samples that were quenched in the agitating salt bath, unlike the samples quenched in calm salt bath. However, the fraction of the ausferrite phase in all of the samples is smaller than expected, which means that chemical composition of the ductile iron is questionable. It is possible that carbon content is lower than what is presented in the chemical composition, so carbon diffusion cannot enrich retained austenite in greater amount and therefore there will be less ausferrite phase. Also, the holding time at the austempering temperature should be somewhat greater, up to 2 hours, so that more ausferrite is produced.

Further mechanical tests have confirmed these presumptions. It is shown that both hardness and toughness are dependent on the final microstructure and amount of ausferrite phase. Obtained mathematical models for hardness and toughness prediction will be used in future works and can significantly improve future experiments and help better understand properties of ADI.

Acknowledgements: This work has been fully supported by the Croatian Science Foundation under the project 5371.

\section{References}

1. Behera G., Sohala S. R., Effect of copper on the properties of austempered ductile iron castings. Bachelor thesis. Department of Metallurgical and Materials Engineering, National Institute of Technology, Rourkela, India, (2012).

2. Sidjanin L., Smallman R. E., Mater. Sci. Tech. - Lond., 8, pp. 1095, (1992).

3. Elliot R., Heat Treatments of Metals. 3, pp. 55, (1997).

4. Chandler H., Heat treaters guide: practices and procedures for irons and steels. ASTM International, 2 Sub edition (December 1995).

5. Sharma A., Singh K.K., Gupta G.K., "Study on the Effects of Austempering Variables and Copper Addition on Mechanical Properties of Austempered Ductile Iron", AIMTDR, India, 2016.

6. Harding R. A., Kovove Mater., 45, p. 1, (2007).

7. Sidjanin L., Smallman R. E., Young J. M., Acta Mater., 42, pp. 3149, (1994). doi:10.1016/0956$\underline{7151(94) 90412-X}$

8. Rajnovic D., Eric O., Sidjanin L., The standard processing window of alloyed ADI materials. Kovove Mater., 50, pp. 199-208, (2012).

9. Gagne, M., „The Sorelmetal Book of Ductile Iron“, Rio Tinto Iron \& Titanium, Montreal, Kanada, 2004.

10. ASM Metals Handbook Volume 04 - Heat Treatment, "Heat Treating of Ductile Irons", p. 1498.

11. Dubal G. P, „Salt bath Quenching“, Advanced Materials \& Processes, Birmingham, December 1991.

12. Hef Durferrit, http://www.hefdurferrit.de/en/.

13. Živković D., Gabrić I., Dadić Z., Čatipović N., Vrljičak I., “Analysis of austempering treatment parameters on properties of ductile iron EN-GJS-400", Zbornik radova = Proceedings, Hrvatsko društvo za strojarske tehnologije, MTSM 2015, Split, 2015.

14. Čatipović, N., Živković, D., Dadić, Z., Sučić, A., Ljumović, P., “Utjecaj izotermičke temperature i vremena držanja na mikrostrukturu i tvrdoću izotermičkog žilavog lijeva”, MTSM 2015, Split, rujan 2015.

15. Eric O., Rajnovic D., Zec S., Sidjanin L., Jovanovic M. T., Mater. Charact., 57, pp. 211, (2006). doi: 10.1016/j.matchar.2006.01.014

16. O. Eric, L. Sidjanin, Z. Miskovic, S. Zec, M. T. Jovanovic, “Microstructure and toughness of Cu, Ni Mo austempered ductile iron", Mater. Lett. 58 (2004) 2707 to 2711.

17. B.V. Kovacs, „A Austempered Ductile Iron: Fact and Fiction“, Mod. Cast., March 1990, p 38-41.

18. L. Sidjanin, D. Rajnovic, O. Eric and R. E. Smallman, “Austempering study of unalloyed and alloyed ductile irons", Materials Science and Technology 26 Vol. 5, (2010), p. 567-571, doi:10.1179/174328409X407524. 